\title{
Analisis Tindakan Mandiri Perawat Kamar Bedah Di Rumah Sakit
}

\author{
${ }^{1}$ Khairul Nasri \\ ${ }^{2}$ Tuti Afriani \\ 3. Sarvita \\ 4.Aat Yatnikasari
}

\author{
1,2,3, Universitas Indonesia \\ ${ }^{4}$ Rumah Sakit Anak dan Bunda Harapan Kita, Jakarta, Indonesia'
}

\begin{abstract}
Alamat Korespondensi :
Khairul Nasri

Universitas Indonesia

Khairulnasri73@gmail.com*
\end{abstract}




\begin{abstract}
ABSTRAK
Pendahuluan: Tindakan mandiri perawat dikamar bedah sering tidak dikerjakan karena perawat lebih banyak mengerjakan pekerjaan kolaborasi atau pekerjaan pelimpahan wewenang. Tujuan penelitian ini adalah meningkatkan pemahaman dan implementasi tindakan mandiri perawat di kamar bedah. Metode yang digunakan dalam penelitian ini adalah study analysis. Analisis menggunakan pendekatan diagram tulang ikan (fish bone) data dikumpulkan sejak awal kegiatan residensi. Wawancara dengan manajer keperawatan dan menyebarkan kuisioner dilanjutkan analysis menggunakan fishbone. Berdasarkan analisis fish bone didapatkan data bahwa perawat kamar bedah kurang memahami apa saja yang termasuk tindakan mandiri-delegasi dan mandat. Hasil wawancara dengan kepala ruangan kamar bedah didapatkan data perawat belum mampu laksana melakukan edukasi preoperasi pasien diruangan rawat sehari sebelum tindakan bedah di lakukan karena kesibukan pekerjaan. Kepala ruangan juga menyampaikan perawat masih kurang memahami mana saja tindakan mandiri, delegasi dan mandat di kamar bedah. Hasil Kuisioner data demografi sebaran umur $30-49$ tahun 84,6\%, jenis kelamin perempuan 56,4 Tingkat pendidikan D3 56,4 \%, Masa kerja 1-10 tahun 42,30\%, Level perawat klinik: PK I 43,6 \%, PK II 7,7 \%, PK III 48,7 \%. Status kepegawaian PNS/ASN 84,6 \%. Kesimpulan : perlu meningkatkan pemahaman tentang tentang implementasi tindakan mandiri-delegasi-mandat di kamar bedah. Rekomendasi : membuat daftar list tindakan mandiri-delegasi-mandat di kamarbedah
\end{abstract}

\title{
Kata Kunci : Delegasi, Mandat, Tindakan Mandiri
}

\begin{abstract}
ABTRACT
Introduction: The independent action of nurses in the surgical room is often not done because nurses do more collaborative work or delegation of authorityThe purpose of this study was to improve understanding and implementation of nurses' independent actions in the operating room. Methods The method used in this research is study analysis. The analysis used a fishbone diagram approach. Data was collected from the beginning of the residency activity. Interview with nursing managers and distributing questionnaires followed by analysis using fishbone. Based on the fishbone analysis, it was found that the surgical room nurses did not understand what included independent delegation and mandate measures. The results of the interview with the head of the operating room, the nurse was not able to carry out the education of patients in the ward the day before the surgery was carried out because of the busy work. The head of the room also conveyed that the nurses still did not understand which independent actions, delegations and mandates were in the operating room. Questionnaire results of demographic data distribution of age $30-49$ years $84.6 \%$, female gender 57.69 , education level D3 $61.53 \%$, working period 1-10 years $42.30 \%$, Level of clinical nurses: PK I 34.61\%, PK II 7.69\%, PK III $57.69 \%$. Employment status for ASN $88.46 \%$. Conclusion: there is a need to increase understanding of the implementation of delegate-mandated self-treatment in the operating room Recommendation: create a delegate-mandateindependent action list in the operating room
\end{abstract}

\section{Keywords: Delegates, Mandate, Independent Action}




\section{PENDAHULUAN}

Peranan perawat dikamar bedah penting dimulai dari persiapan pasien dan kesiapan ruangan operasi. Perawat kamar bedah melakukan tindakan mandiri maupun tindakan kolaborasi sebagai perawat scrub dan perawat sirkuler. Pertanyaannya "Apakah perawat kamar bedah sudah memahami dan mengimplementasikan tindakan mandiri perawat dikamar bedah?" Banyak yang beranggapan bahwa perawat kamar bedah hanya mempunyai pekerjaan sebagai asistensi ahli bedah saja sedangkan tindakan mandiri perawat banyak dan berfariasi mulai dari ruangan penerimaan pasien, kamar bedah dan ruang pemulihan (Simamora, R.H, 2019).

Sebelum pasien menjalani tindakan operasi diperlukan persiapan pasien baik fisik maupun mental. Salah satu peran perawat kamar bedah sebagai educator fase preoperasi yaitu memberikan penjelasan dan edukasi pada pasien tentang prosedur bedah, obat-obatan, pembatasan makanan dan minum, dan persiapan fisik lainnya, termasuk hal-hal yang akan dilakukan pasca operasi (Al Islam, at. al, 2019)

Tindakan memberikan edukasi pre operasi pada pasien merupakan bagian dari tindakan keperawatan sejalan dengan Kementerian kesehatan Republik
Indonesia, 2014 disebutkan bahwa praktik keperawatan sebagai pemberi asuhan keperawatan diberikan secara legal oleh undang-undang dan Negara Republik Indonesia. Penelitian yang dilakukan oleh (Kurniawan,at. al, 2013) di RDUD Kudus pada tahun 2010 terdapat 221 pasien yang menjalankan operasi. Dari data tersebut, didapatkan angka batal operasi sebayak 10 $\%$ akibat kecemasan yang dialami oleh pasien tidak teratasi. Disini terlihat betapa pentingnya peran perawat dalam memberikan edukasi pada pasien sebelum dilakukan operasi.

Tindakan pembedahan merupakan peristiwa komplek yang menegangkan, sehingga selain mengalami gangguan fisik akan memunculkan pula masalah psikologis yang dapat berakibat pada perubahan fisiologis pasien sebelum menjalani operasi. Salah satu intervensi yang dapat membantu menurunkan kecemasan pasien dalam menghadapi operasi adalah tindakan psikoedukasi yang diberikan oleh perawat untuk meningkatkan pengetahuan pasien menjadi lebih memahami tindakan operasi dengan segala resikonya (Ayuningtyas. VD, at. al, 2018)

Pada tatanan asuhan, memberikan bimbingan dalam meningkatkan pengetahuan pasien menjelang dilakukan tindakan operasi menjadi standar praktik 
perawat professional (Astuti, 2011). Dengan memberikan berbagai informasi, pasien menjadi lebih siap menghadapi operasi. Perawat dapat memberikan intervensi mandiri perioperatif salah satunya adalah dengan memberikan edukasi preoperasi (Kurniawan A, 2018). Disamping tindakan mandiri perawat kamar bedah juga terdapat tindakan kolaborasi perawat yang dipengaruhi oleh eksistensi, kredibilitas dan kompetensi perawat yang di akui sebagai insan professional.

Menurut (Fakih, M, 2013)ada 3 fungsi perawat yaitu : pertama fungsi independen perawat dalam memberikan asuhan keperawatan berdasarkan ilmu dan kiat keperawatan secara mandiri dan bertanggungjawab, tidak tergantung pada profesilain. Kedua Fungsi interdependen fungsi ini dilakukan dalam kelompok/tim yang bersifat saling ketergantungan di antara satu dengan yang lainnya. Ketiga fungsi dependen merupakan fungsi perawat dalam melaksanakan kegiatannya atas pesan atau instruksi dari perawat lain/profesi lain sebagai tindakan pelimpahan tugas yang diberikan.

Menurut (Salsabila, 2019) kewenangan terdiri dari wewenang atributif dan non atributif. Wewenang atributif adalah kewenangan yang diberikan dari peraturan perundang- undangan atau Negara. Penerima wewenang bertanggungjawab sepenuhnya atas akibat yang timbul dari wewenang tersebut. Kewenangan Non atributif adalah kewenangan yang di berikan oleh profesi lain yang memiliki kewenangan dan kompetensi yang lebih tinggi. Kewenangan non atributif terbagi menjadi 2 yaitu : Pertama Mandat yaitu wewenang yang diberikan oleh profesi dokter pada perawat tanpa menghilangkan tanggungjawab hukum dari dokter atau tindakan tersebut dibawah pengawasan dokter. Kedua Delegasi adalah wewenang yang diberikan oleh profesi dokter kepada perawat yang disertai dengan pelimpahan tanggungjawab secara hukum.

Delegasi bukanlah suatu system untuk mengurangi tanggungjawab, melainkan cara membuat tanggungjawab tersebut menjadi bermakna. Pelimpahan wewenang hanya dapat diberikan pada perawat Ners atau perawat vokasi yang sudah terlatih.

\section{METODE PENELITIAN}

Metode yang digunakan dalam penelitian ini adalah study analysis. Analisis situasi menggunakan pendekatan diagram tulang ikan (fish bone) yang terdiri dari man, material, method,machine, money dan enviromen. Data dikumpulkan sejak awal kegiatan residensi yaitu dimulai wawancara dengan 
manajer keperawatan rumah sakit $X$. Dilanjutkan dengan memberikan kuisioner menggunakan aplikasi goole form keseluruh perawat kamar bedah sebanyak 39 orang.

Data yang sudah di peroleh kemudian dikumpulkan dan dianalisis dengan menggunakan diagram fishbone untuk menemukan masalah yang terjadi. Setelah beberapa masalah di temukan lalu ditetapkan perioritas masalah untuk menentukan strategi penyelesaian masalah menggunakan plan of action (POA). Selanjutnya dilakukan dengan proses keperawatan sebagai dasar untuk melakukan implementasi. Implementasi berdasarkan rencana kegiatan yang sudah di susun di POA. Implementasi tersebut berupa sosialisasi daftar tindakan mandiriperawat. Daftar tindakan mandiri perawat disusun berdasarkan level perawat klinis dan berdasarkan tugas perawat scrub dan perawat sirkuler.

\section{HASIL PENELITIAN}

Data awal diperoleh saat dilaksanakan wawancara terhadap manajer keperawatan rumah sakit $\mathrm{X}$ selanjutnya dilakukan wawancara lebih mendalam dengan kepala ruangan kamar bedah. Didapatkan gambaran bahwa implementasi tindakan mandiri perawat dikamar bedah masih belum berjalan, khususnya edukasi pada pasien diruang rawat sebelum tindakan pembedahan dikerjakan. Sedangkan tindakan mandiri yang lainnya oleh perawat scrub dan perawat sirkuler sudah berjalan dengan baik, namun menurut kepala ruangan terkadang masih ditemukan beberapa tindakan yang tidak dikerjakan disebabkan kesibukan pekerjaan atau karena terburuburu. Kepala ruangan mengatakan belum dipahami secara mendalam oleh perawat, tindakan apa saja yang masuk kedalam tindakan mandiri, delegasi dan mandat. Perawat sering kali sulit membedakan tindakan mandiri perawat dengan tindakan delegasi dan mandat.

\section{Proses keperawatan}

Pengkajian : Pengkajian adalah upaya mengumpulkan data secara lengkap dan sistematis untuk dikaji dan dianalisis sehingga masalah keperawatan yang dihadapi pasien baik fisik, mental, sosial maupun spiritual dapat ditentukan. Tahap ini mencakup tiga kegiatan, yaitu pengumpulan data, analisis data dan penentuan masalah kesehatan serta keperawatan (Simamora, R.H, 2019).

Diagnosa keperawatan suatu pernyataan yang menjelaskan respon manusia (status kesehatan atau resiko perubahan pola) dari individu dimana perawat secara akuntabilitas dapat mengidentifikasi dan melakukan implementasi secara pasti untuk menjaga 
status kesehatan, menurunkan, mambatasi, mencegah atau merubah. Diagnosa keperawatan yang sering muncul pada pasien yang akan dilakukan tindakan operasi adalah rasa takut atau cemas (Kusumawardhani, 2016)

\section{Rencana}

keperawatan.

Dokumentasi rencana keperawatan dirancang teroganisasi sedemikian rupa sehingga perawat mudah dan cepat Gambar : Diagram Fish bone melakukan identifikasi serta melakukan intervensi secara berkesinambungan.

\section{Implementasi}

keperawatan

merupakan aplikasi dari rencana tindakan untuk mencapai tujuan yang sudah ditentukan.

Evaluasi berisi kriteria keberhasilan proses dan keberhasilan tindakan keperawatan yang sudah dilakukan

\section{CAUSE}

EFFECT

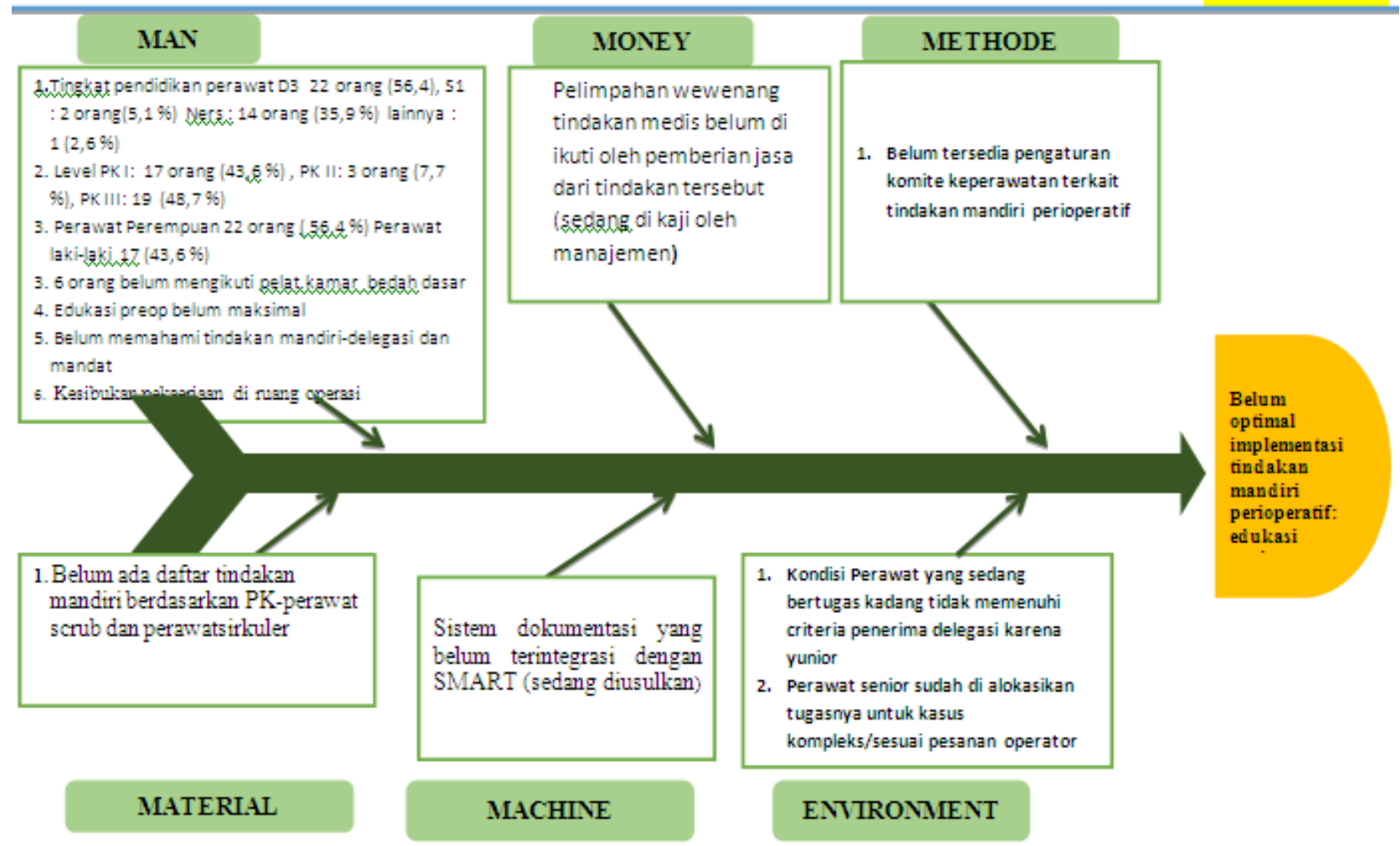


Berdasarkan analisis fish bone dibuatlah strategi untuk menyelesaikan masalah yang ada untuk selanjutnya disusun plan of action (POA) sebagai rencana tindakan yang akan diimplementasikan. Rencana implementasi adalah membuat daftar tindakan mandiri perawat-delegasi dan mandat. Selanjutnya daftar tersebut akan disosialisasikan kepada perawat kamar bedah. Monitoring dan evaluasi akan dilakukan secara berkala oleh kepala ruangan untuk disampaikan kepada Kepala Bidang Keperawatan sebagai laporan.

Implementasi Tahap pertama penulis melakukan review terhadap tindakan mandiri perawat dikamar bedah yang sudah berjalan selama ini. Penulis juga melakukan review terhadap tindakan pelimpahan wewenang delegasi dan mandat yang sudah berjalan. Tahap kedua penulis melanjutkan dengan melakukan literatur review untuk mendapatkan sumber terbaru tentang implementasi tindakan mandiri dikamar bedah. Berdasarkan referensi terbaru hasil telaah jurnal didapatkan data bahwa dengan melakukan tindakan keperawatan edukasi preopertif sebagai intervensi mandiri perawat, dapat mengurangi kecemasan pasien sebelum operasi dikerjakan. Salah satu tindakan mandiri perawat tersebut adalah edukasi yang diberikan pada fase pre operasi, bermanfaat untuk menyingkirkan kecemasan pasien (Kusumawardhani, 2016).

Tahap ketiga adalah pelaksanaan sosialisasi tindakan mandiri perawat pada seluruh perawat kamar bedah. Menyusun daftar tindakan mandiri perawat berdasarkan level perawat klinis (PK) dan berdasarkan tugas perawat scrub dan sebagai perawat sirkuler. Menyusun daftar tindakan pelimpahan wewenang delegasi dan mandat untuk memudahkan perawat melihat perbandingan tindakan tersebut. Konsultasi dilakukan kepada dosen pembimbing akademik dan pembimbing lahan praktek. Setelah mendapatkan masukan dari pembimbing, penulis melakukan perbaikan untuk disempurnakan

\section{Manfaat melakukan tindakan} mandiri terstandarisasi.

Keselamatan pasien (Patient Safety) merupakan sesuatu yang jauh lebih penting dari pada sekedar efisiensi pelayanan. Perilaku yang tidak aman, lupa, kurangnya perhatian atau kurang motivasi, kecerobohan, tidak teliti dan kedakmampuan memperdulikan, tidak menjaga keselamatan pasien akan berisiko terjadinya kesalahan dan akan mengakibatkan pasien, Near Miss (Kejadian Nyaris Cedera/KNC) atau 
Adverse Event, KTD ( Kejadian Tidak Diharapkan)

\section{PEMBAHASAN}

Perawat kamar bedah secara histori diartikan sebagai perawat yang memberikan asuhan klinis kepada pasien selama operatif dikamar operasi, namun secara tanggung jawab, tugas perawat kamar bedah diperluas untuk merawat pasien bedah preoperasi hingga periode pasca operasi. Berdasarkan data wawancara dengan kepala ruangan didapatkan data bahwa perawat kamar bedah masih kurang memahami tindakan perioperatif mana saja yang termasuk kedalam tindakan mandiri, delegasi dan mandat.

Menurut Association of Peri Operative Registered Nurses (2015), perawat bedah merupakan perawat yang mengembangkan rencana asuhan keperawatan pasien yang akan menjalani operasi dan mengkoordinasikan tindakan keperawatan mandiri serta tindakan kolaborasi lain yang akan diterima oleh pasien. Dalam menjalankan tugas seorang perawat kamar bedah menggunakan standar, pengetahuan, penilaian, dan keterampilan yang berdasarkan pada prinsip-prinsip asuhan keperawatan mandiri secara ilmiah. Perawat kamar bedah memiliki peran yang sangat strategis terhadap keselamatan pasien agar terhindar dari cidera selama dikamar operasi, hal ini dikarenakan perawat kamar bedah memiliki peranan yang sangat besar dalam hal pelayanan terhadap pasien bedah. Dalam perannya dibidang mutu asuhan dan keselamatan pasien.

Perawat kamar bedah harus mampu membedakan antara tindakan mandiri perawat, pelimpahan wewenang dan mandat ( Yeni V, Budiarsih, 2019). Perawat kamar bedah membutuhkan daftar tindakan mandiri keperawatan perioperatif berdasarkan level perawat klinis (PK) I sampai PK V. Kewenangan melakukan tindakan mandiri disetiap level perawat klinis akan berbeda-beda. Level perawat klinis I perlu mendapatkan bimbingan dari PK II, dan PK II mendapatkan bimbingan dan pendampingan oleh PK III, begitu seterusnya. Setiap level perawat klinis dan area yang berbeda mempunyai kewenangan yang berbeda pula. Pada area preoperatif kewenangan PK I akan berbeda dengan PK II, dan begitu juga dengan PK III dan seterusnya. Kewenangan tindakan mandiri perawat csrub dan perawat sirkuler mempunyai spesifikasi masingmasing. Perawat scrub atau di Indonesia juga dikenal sebagai perawat instrument merupakan perawat kamar bedah yang memiliki tanggungjawab terhadap manajemen area operasi dan area steril 
pada setiap jenis pembedahan (Wahyuningsri, at.al, 2017).

Menurut

Association

of

Perioperative Registered Nurse

(AORN,2015), perawat scrub bekerja langsung dengan ahli bedah dibidang steril, operasional instrumen, serta bagian lain yang dibutuhkan selama prosedur operasi. Perawat sirkuler merupakan perawat yang memiliki keterampilan khusus dan mempunyai sertifikat keahlian yang bertanggungjawab untuk mengelola asuhan keperawatan pasien dikamar operasi dan memfasilitasi semua keperluan tim bedah dengan tim perawatan lain yang diperlukan untuk menyelesaikan tindakan operasi. Perawat sirkuler juga bertanggungjawab untuk menjamin terpenuhinya perlengkapan yang dibutuhkan oleh perawat scrub dan mengobservasi pasien tanpa menimbulkan kontaminasi terhadap area steril, Muttaqin, 2009 dalam (Wahyuningsri, at.al, 2017).

Pendapat perawat sirkuler sangat dibutuhkan dan sangat membantu, terutama dalam mengobservasi penyimpangan teknik aseptic selama prosedur operasi. Perawat kamar bedah melalui peran sebagai edukator memastikan persiapan perioperatif sudah berjalan sesuai dengan standar. Menurut (Kusumawardhani, 2016) implementasi tindakan mandiri perawat preoperatif diantaranya memberikan edukasi pre operasi berguna untuk menyingkirkan kecemasan pasien sehingga pasien merasa lebih tenang dalam menghadapi operasi.

Edukasi yang diberikan meliputi langkah - langkah prosedur preoperasi, intra operasi dan pascaoperasi. Selain itu, pasien juga diminta mengosongkan kandung kemih, menggunakan baju operasi, memotong kuku, melepaskan perhiasan, menghapus make up serta menghapus cat kuku dan penjelasan mengenai pengawasan yang dilakukan diruangan pemulihan. Kegiatan edukasi ditutup dengan doa sebelum pasien masuk kamar operasi.

Usia berhubungan dengan kematangan jiwa dan kedewasaan berfikir logis dalam bekerja. Semakin bertambah usia akan lebih banyak pengalaman dalam mengambil sebuah keputusan, matang dalam mengendalikan emosi, lebih sopan, dan lebih memiliki komitmen dalam bekerja (Pundar, et al, 2019). Umur produktif seseorang dalam bekerja adalah umur 25 -40 tahun karena pada usia tersebut karir mencapai puncak. Usia perawat kamar bedah RS : usia 20-29 tahun $=6$ perawat $(15,38 \%), 30-39$ tahun $=17$ perawat $(43,58 \%)$, usia $40-49=12$ perawat $(30,76 \%)$ dan usia $>50$ tahun $=$ 4 perawat $(10,25 \%)$. Berdasarkan sebaran 
usia perawat kamar bedah RS sebanyak 17 perawat ( $43,58 \%)$ berada pada rentang usia 30-39 tahun. Ini menunjukan bahwa perawat dengan usia produktif mendominasi dikamar bedah RS.

Jenis kelamin adalah karakteristik seseorang berdasarkan gender. Sebaran data perawat di RS menunjukan perawat wanita lebih banyak (56,4 \%) dibandingkan dengan perawat laki-laki $(43,6 \%)$. Banyak pendapat bahwa perbedaan jenis kelamin berhubungan dengan kemampuan menyelesaikan masalah. Perempuan mempunyai kelebihan dalam penguasaan naluri dalam memberikan asuhan keperawatan, dan memeiliki kemampuan untuk mngerjakan pekerjaan berdasarkan standar operasional, sedangkan laki-laki lebih mengemukan logika dan lebih agresif. Jenis kelamin memiliki korelasi positif terhadap kinerja (Nofiyanto, et al, 2018)

Tingkat pendidikan memilki efek terhadap asuhan keperawatan yang akan diterima oleh pasien. Dalam penelitian ini, menunjukan bahwa mayoritas perawat dengan tingkat pendidikan D3 keperawatan 56,4\% dari 39 responden. Tingkat pendidikan sangat berpengaruh terhadap tingkat pengetahuan perawat dalam hal teoritis dan praktisi, perawat dengan tingkat pendidikan D3 keperawaan lebih kompeten dalam hal praktisi.
Pendidikan adalah proses seseorang belajar dan berusaha untuk mengembangkan potensi dirinya. Mengembangkan wawasan untuk memiliki ketrampilan dan semakin tinggi pendidikan seseorang, maka wawasan yang dimiliki orang tersebut akan semakin luas tingkat pengetahuannya, akan tetapi perlu ditekankan, bukan berarti seseorang yang berpendidikan rendah mutlak berpengetahuan rendah (Eriawan, 2013).

Hasil Penelitian ini juga sejalan dengan hasil penelitian yang dilakukan (Amriyanti, at.al, 2013) tentang hubungan edukasi perawat saat pre operatif dengan pengetahuan post operatif pada pasien pembedahan di RS PKU Muhammadiyah Gombong menyatakan dari 26 responden berdasarkan tingkat pendidikan mayoritas D3 keperawatan yaitu $(86,62 \%)$. Tingkat pendidikan dari perawat menentukan mudah tidaknya pasien memahami edukasi yang diperoleh. Jadi semakin tinggi tingkat pendidikan perawat semakin tinggi pula keahlian dalam praktik memberikan edukasi kepada pasien. Berdasarkan uraian diatas, dapat disimpulkan bahwa perawat dengan pendidikan D3 keperawatan perlu meningkatkan pendidikan dalam rangka meningkatkan pengetahuan dan keterampilan menangani pasien. Pendidikan diharapkan mampu mengubah 
pola fikir seseorang karena mempengaruhi pengetahuan seseorang.

Level perawat klinis adalah jenjang karir perawat klinis berdasarkan skill dan keterampilan yang dimiliki perawat. Perawat kamar bedah RS, sebaran perawat dengan PK I : 17 perawat (43,6 \%), PK II : 3 perawat $(7,7 \%)$, PK III : 19 perawat ( 48,7 \%). Level PK perawat kamar bedah terlihat belum ideal dimana jumlah perawat PK II 7,7 \% masih sangat sedikit sehingga pendampingan dari PK yang lebih tinggi kepada yang lebih rendah tidak bisa berjalan dengan baik. Perawat kamar bedah juga diisi oleh PK I, idealnya kamar operasi diisi oleh minimal PK II sehingga tindakan mandiri keperawatan dapat berjalan. Alasan manajemen menempatkan PK I di kamar bedah dapat dipahami mengingat keterbatasan tenaga.

\section{Lama bekerja merupakan} lamanya seseorang mengabdikan diri sebagai karyawan didalam lingkup perusahaan/instansi dan menjadi loyalis, membangun inovasi yang mendorong kemajuan untuk meningkatkan pengetahuan dan pengalaman individu sesuai dalam bidangnya (Mar'ati, Et.al, 2010). Lama bekerja perawat kamar bedah berdasarkan data yang didapat adalah masa kerja 1- 10 tahun 42,30\% dari 39 responden, paling sedikit perawat dengan masa kerja 21-30 tahun sebanyak 7,69\%.
Berdasarkan data ini, menunjukan bahwa mayoritas perawat dengan lama bekerja 110 tahun yaitu $42,30 \%$.

Lama bekerja sangat mempengaruhi kematangan dalam penerapan ilmu keperawatan terutama keperawatan perioperatif, kematangan dalam masa kerja ini menunjukan bahwa perawat sudah melewati tahap dimana pengalaman lebih banyak dan ilmu yang didapatkan dari hasil seminar atau pelatihan dapat diaplikasikan kepada pasien. Perawat akan lebih mengetahui mana tindakan mandiri yang harus dikerjakan perawat dana mana tindakan pelimpahan wewenang.

Pesatnya perkembangan ilmu keperawatan di Indonesia terutama keperawatan perioperatif menuntut setiap perawat berusaha meningkatkan wawasan, kognitif dan psikomotor menjadi lebih baik. Pengalaman dan lama bekerja mempengaruhi mutu seseorang dalam hal pengetahuan dan dedikasi dalam mengimplementasikan asuhan perawatan. Individu yang apabila tidak terdapat paksaan dalam menjalankan apa yang menjadi tuntutan bagi dirinya serta mampu melaksanakan tugas-tugas yang diberikan maka hal terkecil atau problem yang dihadapi dapat ditangani dengan baik (Koesindratmono, 2011).

Hasil Penelitian ini sejalan dengan penelitian (Eriawan, 2013) di RSUD 
Soebandi Jember menyatakan 20 responden berdasarkan lama bekerja perawat, memiliki pengaruh terhadap ilmu pengetahuan dan ketrampilan dalam memberikan tindakan keperawatan edukasi. Lama bekerja memberikan pengalaman bagi perawat yang mau berusaha untuk belajar lebih baik dan akan semakin tinggi tingkat keterampilannya. Berdasarkan uraian diatas, dapat disimpulkan bahwa perawat dengan lama bekerja 1-10 tahun cenderung dapat mempengaruhi tingkat keterampilan yang dimiliki oleh perawat dalam mengaplikasikan /memberikan tindakan mandiri edukasi preopertif pada pasien yang akan dilakukan tindakan operasi.

Status kepegawaian perawat kamar bedah RS pada prinsipnya terbagi dalam perawat PNS/ASN, BLU dan kontrak. Data status kepegawaian perawat kamar bedah RS yaitu PNS = 33 perawat $(84,61$ $\%)$, BLU $=5$ perawat $(12,82 \%)$, Kontrak $=1$ perawat $(2,56 \%)$. Perawat dengan status PNS adalah yang paling banyak $(84,61 \%)$. Sesuai dengan penelitian (Hendrajana, et al, 2017) mengatakan bahwa ada hubungan yang bermakna antara status kepegawaian dengan kinerja seorang pegawai, dimana pegawai tetap lebih memiliki kinerja yang lebih baik. Perawat dengan status kepegawaian PNS lebih memiliki keterampilan dalam memberikan asuhan keperawatan pada pasien.

\section{KESIMPULAN}

Edukasi preoperasi adalah tindakan mandiri keperawatan yang merupakan intervensi penting dipahami dan diimplentasikan oleh perawat bedah. Perawat bedah dalam bekerja selalu berkolaborasi dengan profesi lain, sehingga tidak terkesan kalau hanya mengerjakan tindakan kolaborasi saja. Tindakan mandiri perawat hususnya edukasi preoperasi adalah bagian terpenting dari profesi perawat dalam mengantisipasi dampak hukum yang tidak diinginkan. Perawat bedah juga perlu memahami tindakan pelimpahan wewenang delegasi dan mandat sehingga tidak salah menafsirkan suatu tindakan yang akan berdampak terhadap hukum.

Dalam meningkatkan kemampuan dan pengetahuan perawat kamar bedah dibutuhkan peningkatan pendidikan perawat dari D3 Keperawatan ke jenjang yang lebih tinggi sehingga diharapakan mampu memberikan pemahaman tentang tindakan mandiri perawat kamar bedah.

\section{DAFTAR PUSTAKA}

Al Islam, at. al, 2019. (2019). Hubungan Edukasi Perawat Saat Pre Operatif dengan Pengetahuan Post Operatif pada Pasien Pembedahan di RS PKU Muhammadiyah Gombong. Urecol, 105-115.

Amriyanti, at.al, 2013. (2013). Analisis Praktik Lama Waktu Tindakan 
Perawat Pelaksana pada Pasien IGD

Berdasarkan Klasifikasi

Kegawatdaruratan di Rumah Sakit

Umum Daerah Raden Mattaher

Jambi. Jurnal Promosi Kesehatan

Indonesia, 8(2), 111-120.

https://doi.org/10.14710/jpki.8.2.111

Astuti, P. (2011). Pengaruh edukasi preoperasi terstruktur (dengan teori

kognitif sosial) terhadap self-efficacy

dan perilaku latihan post operasi

pada pasien fraktur ekstremitas

bawah dengan pembedahan di surabaya.

Ayuningtyas. VD, at. al, 2018. (2018).

Psikoedukasi terhadap tigkat

kecemasan pada pasien pre operasi

frakturusia remaja, 7(2), 110-116.

https://doi.org/10.31983/jrk.v7i2.3539

Eriawan, at. a. (2013). Hubungan Tingkat

Pengetahuan Perawat dengan

Tindakan Keperawatan pada Pasien

Pasca Operasi dengan General

Aenesthesia di Ruang Pemulihan IBS

RSD Dr. Soebandi Jember. Jurnal

Pustaka Kesehatan, 1(1), 54-61.

Retrieved from

https://jurnal.unej.ac.id/index.php/JP

K/article/view/520

Fakih, M, 2013. (2013). Kedudukan hukum tenaga keperawatan dependen dalam transaksi terapeutik. Yustitia Vol. 2.

Hendrajana, et al, 2017. (2017). Analisis

Hubungan Status Kepegawaian,

Komitmen Organisasional dan

Kinerja Karyawan. E-Jurnal Ekonomi

Dan Bisnis Universitas Udayana, 1, 357-384.

Kementerian kesehatan Republik

Indonesia. (2014). UU No.38 Tahun

2014 Tentang Keperawatan.

Departemen Kesehatan RI.

Koesindratmono, F. (2011). Hubungan

antara Masa Kerja dengan

Pemberdayaan Psikologis pada

Karyawan PT. Perkebunan Nusantara

X (Persero). Insan Media Psikologi,

13(1), 1-7. Retrieved from

http://repository.uinjkt.ac.id/dspace/bi
tstream/123456789/24503/1/MARYA

M-PSI.pdf

Kurniawan,at. al, 2013. (2013). Pengaruh

pendidikan kesehatan pre

operasiterhadap tingkatkecemasan

pada pasien pre operasi Hernia di

RSUD Kudus. FIKkes Jurnal

Keperawatan, 6(2), 139-148.

Kurniawan A, at. al. (2018). Pengetahuan

Pasien Pre Operasi Dalam Persiapan

Pembedahan. Jurnal Penelitian

Keperawatan, 4(2).

https://doi.org/10.32660/jurnal.v4i2.3 25

Kusumawardhani, D. T. (2016). Pengaruh

Edukasi Pre Operasi Terhadap

Tingkat Kecemasan Pada Pasien Pre

Operasi Orif ( Open Reduction

Internal Fixation ) Di Rsupn Dr .

Cipto Mangunkusumo Jakarta.

Mar'ati, Et.al, 2010. (2010). Pengaruh

masa kerja dan tingkat pendidikan terhadap kompetensi karyawan dengan competency based training sebagai variabel intervening, 3(6),

114-135.

Nofiyanto, et al, 2018. (2018). Gambaran peran perawat dalam

pencegahandecubitus di bangsal

Penyakit Dalam Rumah Sakit Di

Jogjakarta. Media Ilmu Kesehatan, 7(1), 89-96.

Pundar, et al, 2019. (2019). Analisis faktor-faktor yang mempengaruhi kepatuhan perawatmelakukan hand hygiene sesuai SPO diruang Kelimutu dan Cempaka RSUDProf.DR.W.Z. Johannes Kupang. CHMK Nursing Scientific Journal volume 3 nomor 2 September 2019, 3(September).

Salsabila, 2019. (2019). Sumber kewenangan pemerintah.

Simamora, R.H, 2019. (2019). The influence of training handover based sbar communication for improving patients safety. Indian Journal of Public Health Research and Development, 10(9), 1280-1285. https://doi.org/10.5958/09765506.2019.02755.4 
Wahyuningsri, at.al, 2017. (2017). Kinerja perawat instrumen dalam

melaksanakan manajemen alat operasi herniotomi hernioraphy (HTHR) di

Instalasi bedahsentral RSUD

Kanjuruhan Kepanjen. Jurnal Ners

Dan Kebidanan (Journal of Ners and Midwifery), 4(2), 174-180.

https://doi.org/10.26699/jnk.v4i2.art.p 174- 180 
Tabel 1 : Karakteristik populasi perawat kamar bedah RS

Jenis

\begin{tabular}{cccccc} 
status kepegawaian & Level PK & lama kerja & Pendidikan & kelamin & umur \\
\hline 39 & 39 & 39 & 39 & 39 & 39 \\
\hline 0 & 0 & 0 & 0 & 0 & 0 \\
\hline & & & & &
\end{tabular}

Tabel 2. Sebaran Umur Perawat Kamar Bedah RS

\begin{tabular}{ccccc}
\hline Umur & Frequency & Percent & Valid Percent & $\begin{array}{c}\text { Cumulative } \\
\text { Percent }\end{array}$ \\
\hline 28 & 4 & 10.3 & 10.3 & 10.3 \\
29 & 2 & 5.1 & 5.1 & 5.1 \\
30 & 4 & 10.3 & 10.3 & 10.3 \\
31 & 3 & 7.7 & 7.7 & 7.7 \\
32 & 4 & 10.3 & 10.3 & 10.3 \\
33 & 1 & 2.6 & 2.6 & 2.6 \\
34 & 1 & 2.6 & 2.6 & 2.6 \\
35 & 1 & 2.6 & 2.6 & 2.6 \\
38 & 3 & 7.7 & 7.7 & 7.7 \\
40 & 6 & 15.4 & 15.4 & 15.4 \\
41 & 1 & 2.6 & 2.6 & 2.6 \\
42 & 1 & 2.6 & 2.6 & 2.6 \\
43 & 2 & 5.1 & 5.1 & 5.1 \\
48 & 1 & 2.6 & 2.6 & 2.6 \\
49 & 1 & 2.6 & 2.6 & 2.6 \\
51 & 2 & 5.1 & 5.1 & 5.1 \\
52 & 1 & 2.6 & 2.6 & 2.6 \\
56 & 1 & 2.6 & 2.6 & 2.6 \\
Total & 39 & 100.0 & 100.0 & 100.0 \\
\hline
\end{tabular}

Tabel 3. Sebaran Jenis Kelamin Perawat Kamar Bedah RS

\begin{tabular}{lcccc}
\hline Jenis Kelamin & Frequency & Percent & Valid Percent & $\begin{array}{c}\text { Cumulative } \\
\text { Percent }\end{array}$ \\
\hline laki-laki & 17 & 43.6 & 43.6 & 43.6 \\
\hline perempuan & 22 & 56.4 & 56.4 & 56,4 \\
\hline Total & 39 & 100.0 & 100.0 & 100 \\
\hline
\end{tabular}


Tabel 4. Sebaran Tingkat Pendidikan Perawat Kamar Bedah RS

\begin{tabular}{lcccc}
\hline Tingkat Pendidikan & Frequency & Percent & Valid Percent & Cumulative Percent \\
\hline D3 Keperawatan & 22 & 56.4 & 56.4 & 56.4 \\
\hline S1 Keperawatan & 2 & 5.1 & 5.1 & 5.1 \\
\hline Ners & 14 & 35.9 & 35.9 & 35.9 \\
\hline lainnya & 1 & 2.6 & 2.6 & 2.6 \\
\hline Total & 39 & 100.0 & 100.0 & 100.0 \\
\hline
\end{tabular}

Tabel 5. Sebaran Level PK Perawat Kamar Bedah RS

\begin{tabular}{ccccc}
\hline Level PK & Frequency & Percent & Valid Percent & $\begin{array}{c}\text { Cumulative } \\
\text { Percent }\end{array}$ \\
\hline PK I & 17 & 43.6 & 43.6 & 43.6 \\
\hline PK II & 3 & 7.7 & 7.7 & 7.7 \\
\hline PK III & 19 & 48.7 & 48.7 & 48.7 \\
\hline Total & 39 & 100.0 & 100.0 & 100.0 \\
\hline
\end{tabular}

Tabel 6. Sebaran Lama Kerja Perawat Kamar Bedah RS

\begin{tabular}{|c|c|c|c|}
\hline Lama kerja (Tahun) & Percent & Valid Percent & Cumulative Percent \\
\hline 3 & 7.7 & 7.7 & 7.7 \\
\hline 4 & 10.3 & 10.3 & 10.3 \\
\hline 2 & 5.1 & 5.1 & 5.1 \\
\hline 4 & 10.3 & 10.3 & 10.3 \\
\hline 1 & 2.6 & 2.6 & 2.6 \\
\hline 2 & 5.1 & 5.1 & 5.1 \\
\hline 1 & 2.6 & 2.6 & 2.6 \\
\hline 4 & 10.3 & 10.3 & 10.3 \\
\hline 2 & 5.1 & 5.1 & 5.1 \\
\hline 2 & 5.1 & 5.1 & 5.1 \\
\hline 1 & 2.6 & 2.6 & 2.6 \\
\hline 2 & 5.1 & 5.1 & 5.1 \\
\hline 2 & 5.1 & 5.1 & 5.1 \\
\hline 2 & 5.1 & 5.1 & 5.1 \\
\hline 2 & 5.1 & 5.1 & 5.1 \\
\hline 2 & 5.1 & 5.1 & 5.1 \\
\hline 1 & 2.6 & 2.6 & 2.6 \\
\hline 1 & 2.6 & 2.6 & 2.6 \\
\hline 1 & 2.6 & 2.6 & 2.6 \\
\hline 39 & 100.0 & 100.0 & 100.0 \\
\hline
\end{tabular}


Tabel 7. Sebaran Status Kepegawaian Perawatkamarbedah RS

\begin{tabular}{lcccc}
\hline & Frequency & Percent & Valid Percent & Cumulative Percent \\
\hline PNS & 33 & 84.6 & 84.6 & 84.6 \\
\hline BLU & 5 & 12.8 & 12.8 & 12.8 \\
\hline Kontrak & 1 & 2.6 & 2.6 & 2.6 \\
\hline Total & 39 & 100.0 & 100.0 & 100.0 \\
\hline
\end{tabular}

